\title{
Understanding the reasons why tourists visit the Kruger National Park during a recession
}

\begin{abstract}
Authors:
Marco Scholtz ${ }^{1}$

Martinette Kruger

Melville Saayman ${ }^{1}$

Affiliations:

${ }^{1}$ Tourism Research in

Economic Environs and

Society (TREES), North-West

University, South Africa
\end{abstract}

Correspondence to:

Martinette Kruger

Email:

martinette.kruger@nwu.ac.za

\section{Postal address:}

Private Bag x6001

Potchefstroom 2520,

South Africa

\section{Dates:}

Received: 15 July 2011

Accepted: 05 Nov. 2012

Published: 26 Feb. 2013

How to cite this article:

Scholtz, M., Kruger, M.

\& Saayman, M., 2013,

'Understanding the reasons

why tourists visit the Kruger

National Park during a

recession', Acta Commercii

13(1), Art. \#168, 9 pages.

http://dx.doi.org/10.4102/

ac.v13i1.168

\section{Copyright:}

(C) 2013. The Authors.

Licensee: AOSIS

OpenJournals. This work

is licensed under the

Creative Commons

Attribution License.
Read online:
The 2008 and 2009 recession increased pressure on travellers to cut costs on luxury items, such as going on holiday, and this has led to a global tourism decline of $8 \%$. This, however, was not the case in the Kruger National Park (KNP) in South Africa where a sustained 1.6\% accommodation unit occupancy growth was experienced. In order to sustain this growth, it is of the utmost importance to determine why people still visited the Park during this period. Thus the aim of the study was to determine why people still visited the KNP amidst the 2008 and 2009 economic recession. A total of 355 completed questionnaires were obtained at the Park during 15 December 2009 - 20 December 2009 (high season) after which various analyses (including factor analysis) were conducted. Six motives were identified and 'escape', 'wildlife experience' and 'family benefits' were rated most important. Push factors were more dominant to the extent that visitors regard taking a holiday to the Park as a necessity. It furthermore seems that visitors adapt their spending behaviour at the Park to still be able to afford the visit. This was the first time that research was conducted at a national park during a recession period and this information is important for South African National Parks, seeing as it provides a better understanding of visitors' behaviour as well as feeling towards the Park (especially during recession), and leads to improved niche marketing and a competitive advantage. This research also provides a better understanding of visitors' behaviour during economic downturns.

\section{Introduction and theoretical background}

During periods of economic prosperity and downturns, the travel and tourism industry has historically behaved like a luxury good. Song and Lin (2010), and Papatheodorou, Rossellóo and Xiao (2010) explain that when an individual's income rises, so does the need for luxury goods and services, seeing as they spend a smaller share of their income on essentials such as clothing and food. The demand for luxury goods such as travel and tourism therefore rises during periods of economic growth. However, during economic recessions, consumers' demand for luxuries, including travel and tourism, decline (Wilkerson 2003) since consumers may prefer to keep their income for essentials of life, such as food, shelter and family necessities (Papatheodorou et al. 2010). According to Fernando and Meedeniya (2009), and Nyaupane, Morais and Graefe (2004), this trend supports Maslow's hierarchy of needs, which states that a person will postpone disposable income as well as recreational activities during tough economic times so that more important needs, such as food, drinks and employment, can stay secure.

Papatheodorou et al. (2010) also state that tourism involves discretionary income and according to Wilkerson (2003) and Bramwell and Lane (2003), it is for this reason that travel and tourism grow during times of economic expansion, but stagnate during economic recessions. Based on the latter, the 2008 and 2009 global financial crisis began in July 2007 and resulted in a slowdown of both developed and developing economies around the world (Fernando \& Meedeniya 2009; Song $\&$ Lin 2010). The recession also significantly influenced the tourism industry, evidenced by the fact that the global demand for travel and tourism has declined by $8 \%$ (Fernando \& Meedeniya 2009; Tourism Review 2009) and the Global Travel and Tourism Economy gross domestic product (GDP) declined by $4.8 \%$ in 2009, whilst almost 5 million tourism-related jobs were also lost (World Trade and Tourism Council [WTTC] 2009). The economic recession also had a negative effect on the tourism industry in South Africa, with domestic travel decreasing by $8 \%$ (South African Tourism [SAT] 2009).

With the afore-mentioned in mind, Fernando and Meedeniya (2009), and Nyaupane et al. (2004) point out that a recession does not necessarily have an influence on an individual's will to travel, but rather on the fact that they might not be able to afford it. This notion is verified when looking at the performance of nature-based tourism during the recession. However, despite restricted finances, the demand for nature-based tourism has increased during the recession and visits to national parks, particularly, have escalated. When looking at national parks in the United States of America (USA), a strong growth was visible in parks during the 2009 period. Some of the parks 
that had huge growth in visitor numbers included parks such as Utah's national parks, where visitation increased with an average of 300000 visitors over the year, Glen Canyon National Recreation Area attracted 13000 more visitors and Arches National Park attracted $7.3 \%$ more visitors, to name but a few (Davidson 2010; Seattle Times 2010). This growth was also evident in South African National Parks, especially in the Kruger National Park (KNP). This raises the question: why do people travel to national parks despite a recession?

The KNP is one of the oldest and most profitable national parks in South Africa, as well as world-wide. The Park was proclaimed in 1926 and recently celebrated its 111th birthday (South African National Parks [SANParks] 2009). The Park is one of the largest game reserves in Africa, covering approximately 20000 square kilometres, which is larger than the area covered by countries such as Israel and the Netherlands. Its length extends 350 kilometres from north to south, and its width 60 kilometres from east to west (Kruger National Park [KNP] 2010). The Park contains a very high diversity of living organisms, including 1982 species of plants, 517 species of birds, 147 species of mammals (including the Big 5) and 114 species of reptiles. With 21 rest camps, two private lodge concessions and 15 designated private safari lodges, the Park caters for a wide variety of visitors. There are nine gates that provide access to the Park, which makes the Park highly accessible from the two provinces surrounding it (Mpumalanga and Limpopo). Visitors can also enjoy a wide variety of recreational activities and facilities at the Park including game drives, photography, bird-watching, accommodation, swimming pools and restaurants, to name but a few.

It is therefore clear that this Park is an all-inclusive holiday destination that provides tourists with a unique nature and leisure experience, making it a major draw-card for both domestic and international tourists (Saayman \& Saayman 2009). The Park therefore acts as a strong magnet for tourists, major export earners, and constitutes an important part of the South African tourism industry (Cook, Yale \& Marqua 2010; Uysal, McDonald \& Martin 1994). Furthermore it comes as no surprise that during the recession period, the KNP experienced a sustained growth in Accommodation Unit Occupancy of 1.6\% (SANParks 2009). One explanation given by researchers for why travel and tourism activity are sustained, or even grow during the recession, is that while spending in general may be a luxury, taking some form of vacation may be a necessity (Wilkerson 2003).

Based on the latter, Fernando and Meedeniya (2009) point out that visits to a destination such as the KNP are essentially driven by the visitors' desire to visit places for leisure, enjoyment and relaxation, whilst also needing the time and money to engage in them (Fernando \& Meedeniya 2009). Lee and Sparks (2007) add that even though an individual's lifestyle is constantly changing according to personal, social, economic and political circumstances, they may still regard their travel-specific lifestyle as important. However, while visitors had less discretionary income to travel because of the recession, they continued to visit the KNP. Therefore, since the decision to visit a destination (in this case a national park) is a directed action that is triggered by a desire to meet a need (Crompton \& McKay 1997; Goossens 2000; Lohmann 2004), it can be assumed that visitors regard travelling to the KNP as a necessity and an important part of their travel lifestyle. Since needs and motivations are interrelated and the existence of the former generates the latter (Kozak 2002), the purpose of this research is to determine why tourists still visit the KNP during a recession.

Travel motivation is considered to be one of the most important variables when making the decision to participate in a tourism activity, seeing as it is a strong force behind all human behaviour (Oh, Uysal \& Weaver 1995). According to Pizam, Neumann and Reichel (1979), as quoted by Swanson and Horridge (2006), Park and Yoon (2009), and Kim and Prideaux (2005), travel motivation refers to a set of needs that causes a person to participate in a tourist activity. Motivational factors are psychological needs that play a significant role in causing a person to feel psychological disequilibrium that may be corrected through a travel experience (Crompton 1979; Kim, Crompton \& Botha 2000). Travel motives can therefore be defined as those factors that create a person's desire to travel (Bhatia 2001). Hence, motivation functions as a trigger for travel behaviour and determines different aspects of tourist activity, such as (1) the reasons for travelling or why, (2) the specific destination or where, and (3) the results obtained or overall satisfaction with the trip (Castaňo et al. 2003).

There are four frequently used theoretical frameworks to explain tourist motivation (Cook et al. 2010), namely (1) Maslow's need hierarchy, (2) Iso-Ahola's escape-seeking dichotomy, (3) the notion of push-pull factors, and (4) the notion of disequilibrium (Crompton 1979; Crompton \& McKay 1997; Dann 1977; Kim, Borges \& Chon 2006:958; Swanson \& Horridge 2006). Maslow (1943) is acknowledged as the best-known work on motivation (Page \& Connell 2009). Maslow argued that an individual's needs fall into five broad categories and that these five categories form a hierarchy beginning with lower order of psychological needs (such as food, water, sleep and shelter) moving through to higher order of self-actualisation needs. This is based on the premise that each of the needs expressed in a category should be satisfied before the individual seeks motivation from the next category of need (Cook et al. 2010; Page \& Connell 2009).

Based on Maslow's hierarchy of needs, it can be assumed that during economic recessions, individuals will defer discretionary income and travel so that more important needs such as food, water and especially employment stay secure (Fernando \& Meedeniya 2009; Nyaupane et al. 2004). However, taking into account that an estimated 1326054 visitors travelled to the KNP during 2008 and 2009 (SANParks 2009), it seems that visitors somewhat disregarded lower order needs and still considered taking a holiday to the national park as being a necessity. Therefore, while Maslow's hierarchy of needs can be useful in demonstrating the source of an individual's initial needs and wants and where the satisfaction of these needs may ultimately lead to the purchase of a holiday (Page \& Connell 2009), in order to find possible explanations for the aforementioned phenomenon, 
the theory of push-and-pull factors may provide more insight into the motives and reasons driving visitors to the KNP during the recession.

Tourism literature emphasises the importance of both push-and-pull factors in shaping tourist motivations and in choosing vacation destinations. The notion of this theory is that tourists are both 'pushed' to travel by personality traits or individual needs and wants, and 'pulled' to travel by appealing attributes of the destination (Cook et al. 2010; Galloway 2002; Kim \& Chaplin 2004). Push motives are person-based determinants of behaviour and comprise both socio-demographic characteristics, such as age, income, education, gender and occupation, as well as a variety of psychological variables that can be grouped under the general headings of needs, personal values and personality (Cook et al. 2010; Galloway 2002; Kim \& Chaplin 2004). Push motives can thus include the following motivations: a person's desire to escape their everyday environment; to rest and relax; for health and fitness reasons; for adventure; for prestige; for social interactions; for novelty seeking; for the exploration of a new area; for enhancements of personal relationships; to evaluate themselves; to learn new things; to satisfy their desire for pampering; to be entertained, and the need to indulge in their personal hobbies (Cook et al. 2010; Zhang and Lam 1999 as quoted by Kim \& Chaplin 2004). In addition, common push factors found in tourism-related studies include knowledge-seeking, relaxation and family togetherness (Jang \& Wu 2006). Pull motives, on the other hand, are features external to a person (Galloway 2002) and include destination attributes, namely, features of attractions that are primarily related to the attractiveness of a destination (Bansal \& Eiselt 2004). These factors therefore 'pull' visitors to the destination and can include social opportunities and attractions, natural and cultural amenities, accommodation and transportation, infrastructure, friendly people, recreational activities, bars and evening entertainment, natural and historical environment, cost, facilities, safety and access (Fakaye \& Crompton 1991; Jang \& Wu 2006; Kim, Lee \& Klenosky 2003).

Klenosky (2002) points out that while push-and-pull factors have generally been characterised as relating to two separate decisions made at two separate points in time, push-and-pull factors should not, however, be viewed as being entirely independent of each other, but rather as being fundamentally related to each other. This notion is supported by Cha, McCleary and Uysal (1995), and Uysal and Jurowski (1994), who also affirmed that while the internal forces push people to travel, the external forces of the destination itself simultaneously pull them to choose that particular destination. It can thus be understood that a visit to a national park is directed by both push-and-pull motives. The latter is verified by previous research done on the push-andpull motives of visitors to national parks and nature areas as outlined in Table 1 below.

TABLE 1: Analysis of previous research on travel motives.

\begin{tabular}{|c|c|c|c|}
\hline Researcher/s & Study topic & Motives & Main findings \\
\hline Afwaritefe (2004) & $\begin{array}{l}\text { Motivations of people to visit Nigerian } \\
\text { National Parks. }\end{array}$ & & $\begin{array}{l}\text { - Self-actualisation } \\
\text { - An educational of cultural context } \\
\text { - Recreational or leisure pursuit }\end{array}$ \\
\hline Uysal, McDonald \& Martin (1994) & $\begin{array}{l}\text { Travel motivations of Australian tourists } \\
\text { to US national parks. }\end{array}$ & 5 factors & $\begin{array}{l}\text { - 'Relaxation/hobbies' } \\
\text { - 'Novelty' } \\
\text { - 'Enhancement of kinship relations' } \\
\text { - 'Escape' } \\
\text { - 'Prestige' }\end{array}$ \\
\hline Tao, Eagles \& Smith (2004) & $\begin{array}{l}\text { Travel motivation of Asian tourists to } \\
\text { Taiwan's Tatoko National Park. }\end{array}$ & & $\begin{array}{l}\text { - Learning about nature } \\
\text { - Participating in recreational activities }\end{array}$ \\
\hline Saayman \& Saayman (2009) & $\begin{array}{l}\text { Travel motivations of visitors to Addo } \\
\text { National Park. }\end{array}$ & & $\begin{array}{l}\text { - Nature } \\
\text { - Activities } \\
\text { - Family } \\
\text { - Escape } \\
\text { - Attractions } \\
\text { - Photography }\end{array}$ \\
\hline \multirow[t]{2}{*}{ Kruger \& Saayman (2010) } & $\begin{array}{l}\text { Comparative study between travel motives } \\
\text { to Tsitsikamma National Park and KNP. }\end{array}$ & Similarities & $\begin{array}{l}\text { - Knowledge seeking } \\
\text { - Nostalgia } \\
\text { - Park attributes } \\
\text { - Escape } \\
\text { - Relaxation }\end{array}$ \\
\hline & & $\begin{array}{l}\text { Dissimilarities } \\
\text { The KNP differed in terms of: }\end{array}$ & $\begin{array}{l}\text { - Activities } \\
\text { - Novelty } \\
\text { - Nature experience } \\
\text { - Photography }\end{array}$ \\
\hline Van der Merwe \& Saayman (2008) & $\begin{array}{l}\text { Travel motivations of tourists to the Kruger } \\
\text { National Park. }\end{array}$ & & $\begin{array}{l}\text { - Nature } \\
\text { - Activities } \\
\text { - Attractions } \\
\text { - Nostalgia } \\
\text { - Novelty } \\
\text { - Escape }\end{array}$ \\
\hline Galloway \& Lopez (1999) & $\begin{array}{l}\text { Sensation seeking and attitudes to aspects } \\
\text { of national parks: a preliminary empirical } \\
\text { investigation. }\end{array}$ & & $\begin{array}{l}\text { - Meet new people. } \\
\text { - Stimulating activities. } \\
\text { - Seek and experience animals living in park } \\
\text { - Facilities such as eating in areas in park which are undisturbed }\end{array}$ \\
\hline \multirow[t]{2}{*}{ Kim, Lee \& Klenosky (2003) } & $\begin{array}{l}\text { Influence of push and pull factors at } \\
\text { Korean National Parks. }\end{array}$ & Push factors & $\begin{array}{l}\text { - Family togetherness and study } \\
\text { - Appreciating natural resources and health } \\
\text { - Escaping from everyday routine } \\
\text { - Adventure and building friendship }\end{array}$ \\
\hline & & Pull factors & $\begin{array}{l}\text { - Key tourist resources } \\
\text { - Information and convenience of facilities } \\
\text { - Accessibility and transportation }\end{array}$ \\
\hline
\end{tabular}

Source: Compiled from sources in table, by authors of this article

KNP, Kruger National Park. 
Collectively, the results in Table 1 show that visitors to national parks and nature areas are primarily pushed by the need to relax or to escape their everyday environment, and pulled by nature as well as the attributes of the park and nature area. These results also confirm the theories of both Kim et al. (2003) and Qu and Ping (1999), that state that pull factors of national parks are different between countries or their locations. Qu and Ping (1999) furthermore claim that different visitors have different motivations for travel and that different visitors may engage in the same (park) element and derive different benefits from the experience. Kerstetter, Hou and Lin (2004) add that that visitors who are engaged in environmentally friendly activities in a nature area for a certain period of time, have their own unique motives for visiting these areas. The latter also proves to be true for South African national parks. Saayman and Saayman (2009) identified six travel motivations of visitors at the Addo Elephant National Park, namely nature, activities, family, escape, attractions and photography, whilst Kruger and Saayman (2010) compared the travel motives of visitors at the KNP and Tsitsikamma National Park. Results revealed that the main motives in both national parks were knowledgeseeking, nostalgia and park attributes, as well as escape and relaxation. KNP differed in terms of activities and novelty, compared with nature experience and photography in the case of the Tsitsikamma National Park.

\section{Purpose of research}

Based on the aforementioned discussion, the purpose of this research is to determine why tourists still visit the KNP during a recession. Although travel motivations to the KNP have previously been determined, it is possible that the recent economic recession had an influence on visitors' motivations and reasons to travel to the Park. The importance of certain motivations could also have changed during this period. It is therefore important to determine the motives of visitors at the Park during this period, since Pan and Ryan (2007) emphasise that in order to continue and maintain a sustainable growth rate, to do effective marketing and apply proper management to national parks, such as the $\mathrm{KNP}$, management should understand and be aware of the underlying reasons why tourists travel. Correspondingly, Kozak (2002) stresses that it is imperative that empirical examination of tourist motivation be undertaken, since this will help to identify the attributes that are to be promoted, or identity markets in which tourist motivations and destination features and resources match. Additionally, research will provide a greater understanding of the importance of travelling to a national park, seeing as no research has to date been conducted on the effects of a recession on visitors' travel motives to South African National Parks.

\section{Methodology}

The method of this exploratory research will be discussed under the following two headings: (1) the questionnaires and (2) statistical analysis.

\section{Questionnaires}

The questionnaire used to survey the Kruger National Park in 2009 was based on the questionnaire used by Saayman and Saayman (2009), Kruger and Saayman (2010) and Van der Merwe and Saayman (2008) at respectively the KNP and Tsitsikamma National Park as well as in other studies done by Kim et al. (2003), Galloway and Lopez (1999) and Uysal et al. (1994), and was adapted with the recent recession in mind. The questionnaire consisted of three sections. Section A captured the demographic details of the visitors (language, gender, age, race, marital status, country of residence, province, highest qualification, and occupation), whilst Section B measured the economic information such as size of tour group, number of visitors paid for, an indication as to whether visitors were visiting for the day or staying overnight, the type of accommodation they were staying in, the number of nights staying in the Park, an indication as to whether it was their first visit to the National Park, the number of previous visits to the Park, the number of visits over the previous three years, as well as their spending dynamics. Section $C$ measured the respondents' travel motivations for visiting the KNP. Twenty-one items were listed and respondents were asked to rate the importance of each item on a five-point Likert scale ( $1=$ Not at all important; 2 = Less important; 3 = Important; 4 = Very important; 5 = Extremely important). Respondents were furthermore asked to describe their feelings towards the Park in one word and they had to indicate whether they considered any alternative destinations before deciding on the Park. In addition, respondents were asked what value-added services they would prefer at the Park, despite the tough economic conditions. The extent to which the economic situation influenced certain aspects pertaining to the respondents' visit to the Park was also measured on a five-point Likert scale $(1=$ Completely; $2=$ To a greater extent; $3=$ To some extent; $4=$ To a lesser extent; $5=$ Not at all). Lastly, respondents were asked to give their opinion on why the KNP was still visited even though the world was in an economic recession. For the purposes of this study, Sections A, B and a portion of C were used. A total of 355 questionnaires were completed out of a possible 400 over a five-day period (15-20 December 2009) by means of the convenience sampling method. Since the profile of visitors to the KNP during December has remained consistent over a period of nine years (2001-2009) (Saayman, Kruger \& Fouché 2009), it can thus be assumed that when applying the Central Limit Theorem as indicated by Israel (2009), a 95\% confidence level will exist in the sample. Fieldworkers were well trained beforehand to ensure that they understood the aim of the questionnaire and to guarantee that the maximum number of questionnaires was completed. Overnight visitors completed questionnaires at Skukuza as well as Satara, seeing as these two camps are the biggest and most popular in the KNP (see Figure 1). Fieldworkers distributed the questionnaires just before sunset and collected them later in the evening. At day visitor areas, including Afsaal, Nkuhlu and Tshokwane, questionnaires were handed out to visitors who were willing to fill them in. Microsoft ${ }^{\odot}$ Excel $^{\odot}$ was used for data capturing and basic data analysis. 


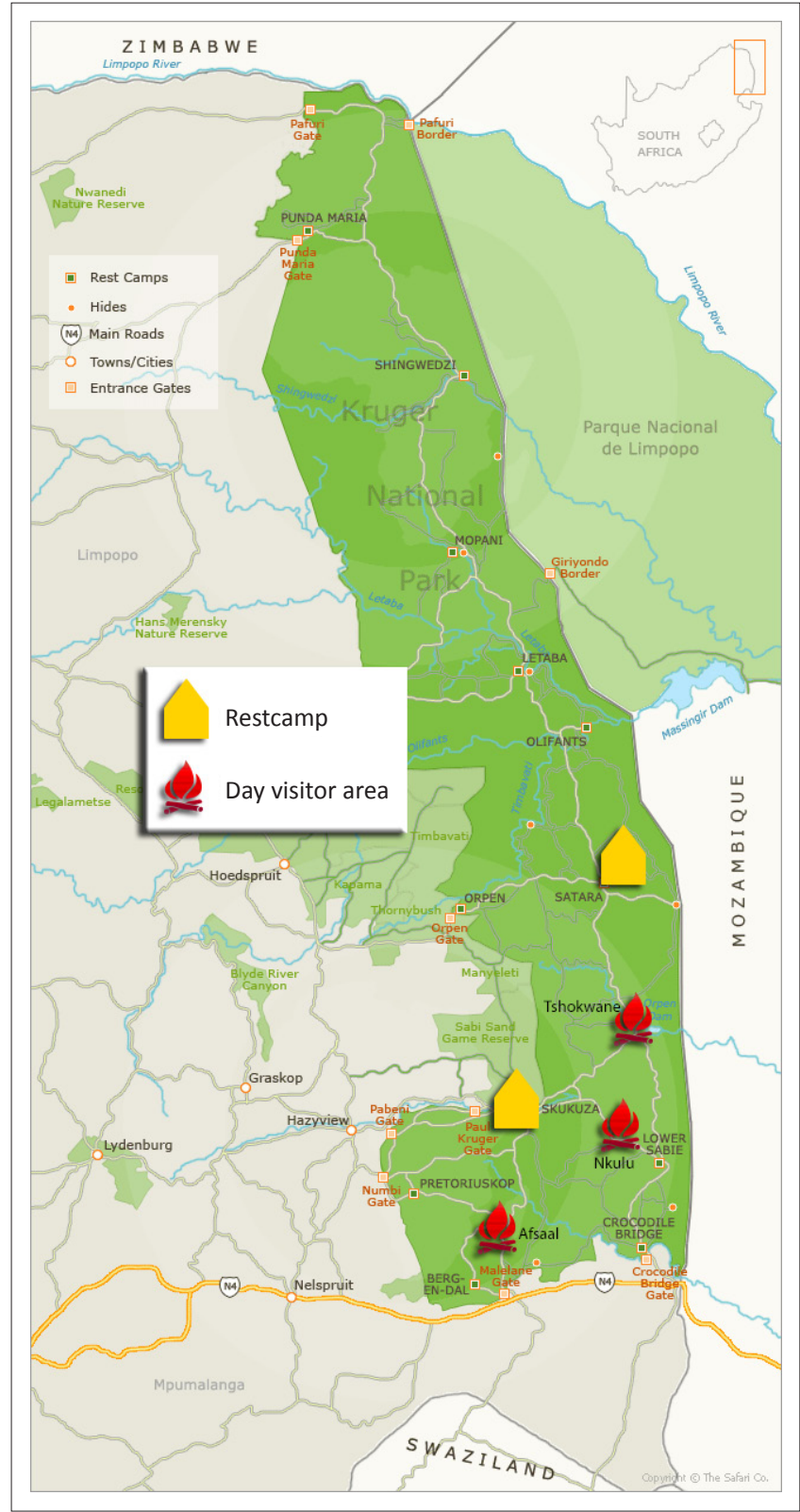

Source: Adapted from TheSafariCo, 2013

FIGURE 1: Kruger National Park.

TABLE 2: Visitor profile at the Kruger National Park (2009).

\begin{tabular}{ll}
\hline Category & Profile \\
\hline Home language & Afrikaans (56\%); English (34\%) \\
Gender & Male (55\%); Female (45\%) \\
Race & White (94\%); Black (3\%); Indian (2\%) \\
\hline Age & $35-49$ years of age (Average: 44) \\
Marital status & Married (63\%) \\
Country of residence & RSA (84\%); Netherlands (4\%) \\
\hline Province of residence & Gauteng (59\%); Mpumalanga (14\%) \\
\hline Level of education & $75 \%$ qualified higher than matric \\
Occupation & Professional (20\%); Self-employed (18\%); \\
\hline Number of people in group & Management (15\%) \\
Overnight visitors' length of stay & $3-4$ people (37\%); 1-2 people (34\%) \\
Number of first visits & $2-4$ nights (22\%); 5-6 nights (21\%) \\
\hline Number of previous visits & First visits (17\%) \\
Number of day visits during last 3 years & No visits (62\%); 1-2 visits (13\%) \\
\hline
\end{tabular}

Source: Compiled from questionnaires, by authors of this article

\section{Statistical analysis}

The analysis of data from this research consists of two stages. The first stage of the analysis compiled a general profile of the visitors to the KNP during December 2009 using the statistical programme SPSS ${ }^{\circledR} 17$ for Microsoft ${ }^{\circledR}$ Windows $^{\circledR}$, release 17.0.0 (SPSS). During the second stage, a principle component factor analysis was done. This factor analysis was done on the 21 motivational criteria by means of SPSS to explain the variance-covariance structure of a set of variables through a linear combination of these variables. In the research, Eigen values were used as criteria. All factors with a loading above 0.3 were included, whilst factors with a loading below this were considered insignificant. Any items that cross-loaded onto two or more factors were assigned to the factor where interpretability was best. The KaiserMeyer-Olkin measure of sampling adequacy was used to indicate whether sufficient data had been collected in order to ensure compact factor structures. In order to determine the reliability of each scale within the factors, a reliability coefficient (Cronbach's alpha) was computed. Factors with a reliability coefficient above 0.6 were considered acceptable for this study. The average inter-item correlations were also calculated as another measure of reliability. According to Clark and Watson (1995), the average inter-item correlation should lie between 0.15 and 0.55 .

\section{Results}

The results will be discussed in two sections: an overview of the profile of visitors to the Kruger National Park will be given first, followed by a discussion of the results from the factor analysis.

\section{Visitor profile to the Kruger National Park}

The main market travelling to the Kruger National Park during December 2009 was white, male, Afrikaans-speaking tourists in their late forties. These tourists were married and well-educated, and worked in Gauteng, South Africa. They preferred to travel in groups of one to four people, and were financially responsible for one to two people in their group. The majority of visitors were overnight visitors who preferred to camp and the length of stay, on average, was three to six nights. The majority of visitors indicated that they had previously visited the Park, with an average of 14 visitations. Visitors to the KNP have visited the Park as overnight visitors once or twice in the past three years, with the day visitors' figures relatively the same compared with the overnight visitors. The findings are laid out in Table 2.

\section{Results of the factor analysis}

The factor analysis (Pattern Matrix), using an Oblimin rotation with the Kaiser Normalisation, identified six factors, which were named according to similar attributes: Factor 1 = Escape; Factor 2 = Finances; Factor 3 = Socialising and exploration; Factor $4=$ Family benefit; Factor $5=$ Wildlife experience; and Factor $6=$ Loyalty. The six motivational factors accounted for $63 \%$ of the total variance. All motivational factors had relatively high reliability coefficients, ranging 
respectively from 0.50 (the lowest) to 0.74 (the highest). The average inter-item correlation coefficients varied between 0.34 and 0.50 for the motivations, which implies internal consistency for all factors. The Kaizer-Meyer-Olkin measure of sample adequacy of 0.81 also indicated that patterns of correlation are relatively compact and thus yield distinct and relative factors (Field, 2005). Moreover, all items loaded onto a factor with loadings greater than 0.3 , and relatively high factor loadings indicate a reasonably high correlation between the delineated factors and their individual items. Any items that cross-loaded onto one or more factors, such as '[ $t$ ]he Park is value for money', which cross-loaded onto factors 1, 2 and 5, were categorised into factors where interpretability was best. This also applied to '[f]or family or to spend time with someone special'; '[t]he Park offers a unique experience' and 'I am loyal towards the Park'. The results of the factor analysis are presented in Table 3 below.

Factor scores were calculated as the average of all items contributing to a specific factor so that it could be interpreted on the original five-point Likert scale of measurement $(1$ = Completely; 2 = To a greater extent; 3 = To some extent; $4=$ To a lesser extent; $5=$ Not at all). As shown in Table 2 , the following attributes were identified, of which factors 1,4 and 5 obtained the highest loading:

\section{Factor 1: Escape}

Escape (Factor 1) has the highest mean value of 4, a reliability coefficient of 0.74 and an average inter-item correlation of 0.5. It included the following activities: relax; get away from routine, and ideal destination. Based on this factor's high mean value, it can be stated that visitors to the KNP want to get away from their daily routine, and that they view the KNP as an ideal destination.

\section{Factor 5: Wildlife experience}

Factor 5 was labelled Wildlife experience and has the second highest mean value (3.9), indicating motivational importance for a variety of wildlife and activity, photography, the Big 5 and a unique experience. Wildlife experience has a reliability coefficient of 0.7 and an item-correlation of 0.37 . This factor reveals that visitors consider the wildlife experience and photography as important motives and reasons to visit the KNP.

\section{Factor 4: Family benefits}

A mean value of 3.3 was measured for Factor 4, with a reliability coefficient of 0.69 and inter-item correlation of 0.36 . This factor was named Family benefits, seeing as it consists of items such as benefits for children, education, Wild Cards, and spending time with family or someone special. Judged against the above-mentioned factors, factors 2, 3 and 6 had the lowest mean values, all obtaining a value of 2.9 .

Finances (Factor 2) has a reliability coefficient of 0.7 and an average inter-item correlation of 0.38 . Under Finances, the following motives were identified: affordable accommodation; activities, restaurants and shops are affordable, and value for money. The low mean value for Finances reveals that visitors did not find the fact that the Park is affordable as an important factor and that they visited the KNP regardless of the financial implications.

TABLE 3: Factor analysis results of visitors' motivations to the Kruger National Park.

\begin{tabular}{|c|c|c|c|c|c|c|}
\hline \multirow[t]{2}{*}{ Motivations } & \multicolumn{6}{|c|}{ Factor } \\
\hline & 1: Escape & 2: Finances & $\begin{array}{l}\text { 3: Socialising } \\
\text { \& Exploration }\end{array}$ & $\begin{array}{l}\text { 4: Family } \\
\text { Benefits }\end{array}$ & $\begin{array}{l}\text { 5: Wildlife } \\
\text { Experience }\end{array}$ & 6: Loyalty \\
\hline To relax & 0.814 & - & - & - & - & - \\
\hline To get away from my routine & 0.709 & - & - & - & - & - \\
\hline The Park is an ideal holiday destination & 0.484 & - & - & - & - & - \\
\hline The accommodation is affordable & - & 0.826 & - & - & - & - \\
\hline The Park has affordable activities, shops and restaurants & - & 0.762 & - & - & - & - \\
\hline $\begin{array}{l}\text { It is the closest National Park, and therefore an affordable } \\
\text { holiday destination }\end{array}$ & - & 0.731 & - & - & - & - \\
\hline The Park is value for money & - & 0.458 & - & - & - & - \\
\hline To spend time with my friends & - & - & 0.717 & - & - & - \\
\hline To explore a new destination & - & - & 0.712 & - & - & - \\
\hline For the benefit of my children & - & - & - & 0.804 & - & - \\
\hline Primarily for educational purposes & - & - & - & 0.637 & - & - \\
\hline I own a Wild Card, therefore I can visit the Park regularly & - & - & - & 0.548 & - & - \\
\hline For family or to spend time with someone special & - & - & - & 0.526 & - & - \\
\hline The wide variety of wildlife and activities in the Park & - & - & - & - & 0.758 & - \\
\hline To photograph animals and plants & - & - & - & - & 0.715 & - \\
\hline It offers the Big 5 & - & - & - & - & 0.647 & - \\
\hline The Park offers a unique experience & - & - & - & - & 0.54 & - \\
\hline Because I grew up with the Park & - & - & - & - & - & 0.828 \\
\hline It is an annual commitment & - & - & - & - & - & 0.649 \\
\hline I am loyal towards the Park & - & - & - & - & - & 0.635 \\
\hline It is a well-known brand & - & - & - & - & - & 0.515 \\
\hline Reliability coefficient & 0.74 & 0.7 & 0.5 & 0.69 & 0.7 & 0.67 \\
\hline Inter-item correlation & 0.5 & 0.38 & 0.34 & 0.36 & 0.37 & 0.34 \\
\hline Mean & 4 & 2.9 & 2.9 & 3.3 & 3.9 & 2.9 \\
\hline
\end{tabular}

Source: Compiled from data derived from questionnaires, by authors of this article 
Socialising and exploration (Factor 3 ) has a reliability coefficient of 0.5 and an inter-item correlation of 0.34 . Activities such as having a good time with friends as well as the exploration of a new destination were most evident within this factor. When reviewing this factor's low mean value, it is apparent that spending time with friends whilst exploring new areas is not that important for visitors to the KNP.

Loyalty (Factor 6) obtained a reliability coefficient of 0.67 and an inter-item correlation of 0.34. Items included in this factor are: people who grew up with the Park; people who visit the Park annually, and people who are loyal towards the Park and the brand. Based on the latter, it becomes clear that visitors are not that 'brand-loyal' towards the Park as part of SANParks, but that they are loyal towards the Park itself. Based on the results, the next section will discuss the findings and conclusions.

\section{Findings and implications}

The aim of this research was to determine the reasons why visitors still travelled to the KNP during the recession. The results revealed six travel motives or reasons for travelling, namely Escape, Finances, Socialising and exploring, Family benefits, Wildlife experience and Loyalty. The main motives to travel to the KNP were to Escape from the everyday environment, to Experience wildlife and nature as well as for Family benefits. Based on these results, the following findings and implications were identified:

Firstly, the results revealed that a combination of pushand-pull factors play a role in a visitor's decision to visit the KNP. This supports the notion by Cook et al. (2010), Kim and Chaplin (2004), and Galloway (2002) that both push (a person's personal intrinsic motives that are Escape, Socialising and exploration, Loyalty and Family benefits) and pull factors (appealing attributes of the Park, namely, Wildlife experience and Finances) play a role in shaping a visitor's motivations and reasons for choosing a holiday destination. Although the motives were dominated by push, the results show the importance of a nature experience to visitors regardless of the recession. This could be because the Park has become part of these visitors' lifestyles or it could even be seen as a necessity. As emphasised by Cha et al. (1995), and Uysal and Jurowski (1994), both the identified push and pull factors should thus be incorporated into the marketing campaigns.

Secondly, corresponding with general travel motivations of previous studies regarding general travel motivation, Escape is also the most important motive for travelling to the KNP. This result supports findings by Uysal et al. (1994), Saayman and Saayman (2009), Kruger and Saayman (2010), Van der Merwe and Saayman (2008), as well as Kim et al. (2003), who identified Escape as an important motive for travel to national parks. Travelling to the KNP can furthermore be seen as a way to deal with or 'escape' from stress and issues as a result of the recession as well as to get away from negative economic news reports. In this sense the Park is seen as a retreat that adheres to the intrinsic needs of visitors.
The latter is verified by Richards (1999), Kim and Pridaux (2005), and Bentrupperbäuer (2005), who regard travelling to national parks to be a 'restorer', whilst Ulrich's (1983) stress reduction theory also emphasises the role of natural settings in generating psycho-physiological recovery from stressful experiences. In addition, since visitors would rather travel to parks close to home in order to cut costs during recessions, the location, proximity and accessibility of the Park to surrounding provinces (Limpopo, Gauteng and Mpumalanga) should also be emphasised in the marketing campaign. Concepts such as 'relaxation', 'escapism', 'proximity', 'convenience', 'break away from routine' and 'KNP as the ideal holiday destination' should therefore be highlighted in promotional messages, seeing as they will reveal how the Park will provide for their intrinsic needs. The latter can also ensure that the KNP gains a competitive advantage.

Thirdly, visitors considered the Wildlife experience to be an extremely important reason to visit the KNP. Similar motives pertaining to Wildlife experience were also identified by Saayman and Saayman (2009), Kruger and Saayman (2010), Van der Merwe and Saayman (2008), as well as Galloway and Lopez (1999). Emphasis should thus be placed on the variety of wildlife and activities, photographic opportunities, the Big 5 and the unique experience offered by the Park, since these aspects can contribute to and enhance the Escape motive. Based on the latter, the KNP should promote the Park's attributes more intensively and brand itself as an 'all-inclusive breakaway and wildlife destination'.

Lastly, even though Finances, Socialising and exploration and Loyalty were considered slightly less important motives compared with the aforementioned reasons, based on the mean values (Table 3), they should not be discarded as key motives for travel to the KNP. Socialising and exploration was also identified by Uysal et al. (2004), Galloway and Lopez (1999), and Kim et al. (2003), while Finances and Loyalty can be regarded as unique motives for travel to the Park. Respondents made it clear that they base their commitment to the Park on their internal motives (push factor) and other Park attributes, rather than on previous experience and the status associated with the brand. This in fact, without the respondents even realising it, shows their high level of loyalty towards the Park. The Park should continue to market the Wild Card (loyalty card) and also bring in other loyalty awards such as discounts on entrance fees or, for example, activities such as game drives for persons visiting for the 10th time in a year, or such like. With regard to Finances, it seems that financial implications did not play a significant role in a visitor's decision to travel to the KNP. However, seeing as visitors regard travelling to the KNP as a necessary part of their travel lifestyle, visitors might have changed their behaviour at the Park, for example, making use of lessexpensive accommodation or participating in fewer activities to still be able to afford the KNP experience. The KNP should therefore continue to offer visitors a range of choices and pride itself in being a 'value for money' destination, irrespective of global economic conditions. This study makes a contribution towards understanding why people travel during degraded 
economic conditions and it also revealed that travelling to natural areas might have become part of a person's lifestyle, which is something that no other study has yet shown.

\section{Conclusions}

This research set out to determine why people still travelled to the KNP despite the 2008 and 2009 economic recession. Based on the results from this study, it is clear that during the recession, the intrinsic push motives played a more important role than pull motives. Therefore, the necessity to visit the Park carried a heavier weight. Greater emphasis was placed on escape and experiencing the nature and wildlife of the Park together as a family. The results furthermore indicate that irrespective of economic constraints, visitors regard travelling to the KNP as a primary need instead of a luxury, and forms a vital and necessary part of their travel lifestyle. The increase in visitation numbers at the Park during the recession also supports the findings of Eagles (2007) that state that visitations to nature areas such as national parks will continue to increase as more people turn to nature tourism. Based on the latter, the KNP should use the marketing implications of this research to sustain its growth rate over the long term - during recessions and times of prosperity. They should words such as 'relax', 'get away', 'tranquillity' and other intrinsic feelings that represent relaxation and the lowering of stress in their marketing, so that people will be able to associate with them and feel compelled to visit the Park.

This was the first time that the influence of the recession on a visitor's motives to travel to a South African national park was determined, and the results provided valuable insight pertaining to the reasons why visitors still travelled to the KNP during the recession. The results especially indicated a shift in visitors' needs, reasons and importance of visiting the Park. It is thus recommended that a further analysis be done to determine how the recession influenced visitors' spending behaviour at the Park, as this will provide further insights into the influence of the recession on visitors to the Park.

\section{Acknowledgments}

The authors would like to thank South African National Parks (SANPARKS) for allowing the research and for fully financing the study as well as all the fieldworkers who helped to collect the data.

\section{Competing interests}

The authors declare that they have no financial or personal relationship(s) which may have inappropriately influenced them in writing this paper.

\section{Authors' contributions}

M.S. (North-West University) was the main study leader whilst M.K. (North-West University) was the co-study leader of M.S. (North-West University) who wrote this article as part of his M.Com in tourism. M.K. (North-West University) and M.S. (North-West University) were responsible for the questionnaire development, M.S. ((North-West University) distributed the questionnaires and collected the data. M.S. (North-West University) and M.K. (North-West University) were responsible for the data analysis as well as the writing of the article. Prof M.S. (North-West University) oversaw the whole process and contributed valuable ideas.

\section{References}

Afwaritefe, O.D., 2004, 'Motivation and other considerations in tourist destination choice: a case study of Nigeria', Tourism Geographies 6(3), 303-330. http://dx.doi. org/10.1080/1461668042000249638

Bansal, H. \& Eiselt, H.A., 2004, 'Exploratory research of tourist motivations and planning', Tourism Management 25(3), 387-396. http://dx.doi.org/10.1016/ S0261-5177(03)00135-3

Bentrupperbäuer, J., 2005. 'Human dimension of the wildlife interactions', in D. Newsome, D.R. Dowling \& S.A. Moore (eds.), Wildlife tourism, p. 112, Channel View Publications, England.

Bhatia, A.K., 2001, International tourism management, Sterling Publishers Private Limited, New Delhi.

Bramwell, B. \& Lane, B., 2003, 'Tourism and sustainable development in an economic downturn', Journal of Sustainable Tourism 11(1), 1-2. http://dx.doi.org/10.1080/ 0966958030866718

Castaňo, J.M., Moreno, A., García, S. \& Crego, A., 2003, 'Aproximación psicosocial a la motivación turística: variables implicadas en la elección de Madrid como destino', Estudios Turísticos 158(1), 5-41.

Cha, S., McCleary, K. \& Uysal, M., 1995, 'Travel motivations of Japanese overseas travellers: a factor-cluster segmentation approach', Journal of Travel Research $33(3), 3-39$

Clark, L.E. \& Watson, D., 1995, 'Constructing volatility: Basic issues in objective scale development', Psychological Assessment 7(3), 309-319. http://dx.doi.org/ 10.1037/1040-3590.7.3.309

Cook, R.A., Yale, L.J. \& Marqua, J.J., 2010, Tourism: The business of travel, 4th edn., Pearson Education, Inc., New Jersey.

Crompton, J.L., 1979, 'Motivations for pleasure vacation', Annals of Tourism Research 6(4), 408-424. http://dx.doi.org/10.1016/0160-7383(79)90004-5

Crompton, J.L. \& McKay, S.L., 1997, 'Motives of visitors attending festival events', Annals of Tourism Research 24(2), 425-439. http://dx.doi.org/10.1016/S01607383(97)80010-2

Dann, G.M.S., 1977 'Anomie, ego-enhancement and tourism' Annals of Tourism Research 4(4), 184-194. http://dx.doi.org/10.1016/0160-7383(77)90037-8

Davidson, L., 2010, 'National park visits boom amid recession', viewed 09 March 2010 from http://www.deseretnews.com/article/700011542/National-park-visitsboom-amid-recession.htm

Eagles, P.F.J., 2007, 'Global trends affecting tourism in protected areas', in R. Bushell \& P.F.J. Eagles (eds.), Tourism and protected areas: benefits beyond boundaries, pp. 27-43, CAB International, United Kingdom. http://dx.doi.org/ $10.1079 / 9780851990224.0027$

Fakaye, P.C. \& Crompton, J.L., 1991, 'Image differences between prospective, firsttime, and repeat visitors to the Lower Rio Grande Valley', Journal of Trave Research 30(2), 10-16. http://dx.doi.org/10.1177/004728759103000202

Field, A.P., 2005, Discovering statistics using SPSS: (and sex, drugs and rock 'n roll), 2nd edn., Sage Publications, London.

Fernando, K. \& Meedeniya, A., 2009, 'Tourism fall out in Sri Lanka due to global recession and other reasons, and its implications for poverty reduction', in Centre for Poverty Analysis 'The impact of the glions for pover for Poverty Analysis 'The impact of the global economic slowdown on poverty and sustainable development docs/48652726/Tourism-Fall-Out-in-Sri-Lanka---presentation

Galloway, G., 2002, 'Psychographic segmentation of park visitor markets: evidence for the utility of sensation seeking', Tourism Management 23, 581-596. http://dx.doi. org/10.1016/S0261-5177(02)00025-0

Galloway, G. \& Lopez, K., 1999, 'Sensation seeking and attitudes to aspects of national parks: a preliminary empirical investigation', Tourism Management 20, 665-671. http://dx.doi.org/10.1016/S0261-5177(99)00031-X

Goossens, C., 2000, 'Tourism motivation and pleasure motivation', Annals of Tourism Research 27(2), 301-321. http://dx.doi.org/10.1016/S0160-7383(99)00067-5

Israel, G.D., 2009, 'Determining sample size', viewed 22 March 2010, from http:// www.edis.ifas.ufl.edu/pdffiles/pd/pd00600.pdf

Jang, S. \& Wu, C.E., 2006, 'Seniors' travel motivations and the influential factors: an examination of Taiwanese seniors', Tourism Management 27(2), 306-316. http:// dx.doi.org/10.1016/j.tourman.2004.11.006

Kerstetter, D.L., Hou, J.S. \& Lin, C.H., 2004, 'Profiling Taiwanese ecotourists using a behavioural approach', Tourism Management 25(4), 491-498. http://dx.doi. org/10.1016/S0261-5177(03)00119-5

Kim, H., Borges, M.C. \& Chon, J., 2006, 'Impacts of environmental values on tourism motivation: The case of FICA Brazil', Tourism Management 27(5), 957-967. http:// dx.doi.org/10.1016/j.tourman.2005.09.007

Kim, N. \& Chaplin, L., 2004, 'Why travel to the FIFA World Cup? Effects of motives, background, interest, and constraints', Tourism Management 25(6), 695-707. http://dx.doi.org/10.1016/j.tourman.2003.08.011 
Kim, S.S., Crompton, J.L. \& Botha, C., 2000, 'Responding to competition: a strategy for Sun/Lost City, South Africa', Tourism Management 21(1), 33-41. http://dx.doi. for Sun/Lost City, South Africa', Tourism
org/10.1016/S0261-5177(99)00094-1

Kim, S.S., Lee, C. \& Klenosky, D.B., 2003, 'The influence of push and pull factors at Korean national parks', Tourism Management 24(2), 169-180. http://dx.doi.org/ 10.1016/S0261-5177(02)00059-6

Kim, S.S. \& Prideaux, B., 2005, 'Marketing implications arising from a comparative study of international pleasure tourist motivations and other travel-related characteristics of visitors to Korea', Tourism Management 26(3), 347-357. http:// dx.doi.org/10.1016/j.tourman.2003.09.022

Klenosky, D.B., 2002, 'The pull of tourism destinations: A means-end investigation', Journa of Travel Research 40(4), 385-395. http://dx.doi.org/10.1177/0047287502040004005

Kozak, M., 2002, 'Comparative analysis of tourist motivations by nationality and destinations', Tourism Management 23(3), 221-232. http://dx.doi.org/10.1016/ S0261-5177(01)00090-5

Kruger, M. \& Saayman, M., 2010, 'Travel motives to Kruger and Tsitsikamma National Parks: A comparative study', South African Journal of Wildlife Research 40(1), 93-102. http://dx.doi.org/10.3957/056.040.0106

Kruger National Park (KNP), 2010, 'History of the Kruger National Park', viewed 21 February 2010, from http://www.krugerpark.co.za/Krugerpark_History-travel/ kruger-national-park-history.html

Lee, S.H. \& Sparks, B., 2007, 'Cultural influences on travel lifestyle: A comparison of Korean Australians and Koreans in Korea', Tourism Management 28(2), 505-518. http://dx.doi.org/10.1016/j.tourman.2006.03.003

Lohmann, M., 2004, New demand factors in tourism, Institut für Tourismus- und Bäderforschung, Nordeuropa.

Maslow, A.H., 1943, 'A theory of human motivation', Psychological Review 50(4), 370 396. http://dx.doi.org/10.1037/h0054346

Nyaupane, G.P., Morais, D.B. \& Graefe, A.R., 2004, 'Nature tourism constraints: A cross-activity comparison', Annals of Tourism Research 31(3), 540-555. http:// dx.doi.org/10.1016/j.annals.2004.01.006

Oh, H.C., Uysal, M. \& Weaver, P.A., 1995, 'Product bundles and market segments based on travel motivations: a canonical correlation approach', International Journal
of Hospitality Management 14(2), 123-137. http://dx.doi.org/10.1016/0278of Hospitality Mana

Page, S. \& Connell, J., 2009, Tourism: A modern synthesis, 3rd edn., Cengage Learning, United Kingdom.

Pan, S. \& Ryan, C., 2007, 'Mountain areas and visitor usage - motivations and determinants of satisfaction: The case of Pirongia Forest Park, New Zealand', Journal of Sustainable Tourism 15(3), 288-308. http://dx.doi.org/10.2167/jost662.0

Papatheodorou, A., Rosselló, J. \& Xiao, H., 2010, 'Global economic crisis and tourism consequences and perspectives', Journal of Travel Research 49(1), 39-45. http:// dx.doi.org/10.1177/0047287509355327

Park, D.B. \& Yoon, Y.S., 2009, 'Segmentation by motivation in rural tourism: A Korean case study', Tourism Management 30(1), 99-108. http://dx.doi.org/10.1016/j. tourman.2008.03.011

Qu, H. \& Ping, E.W.Y., 1999, 'A service performance model of Hong Kong cruise travellers' motivation factors and satisfaction', Tourism Management 20(2), 237-244. http://dx.doi.org/10.1016/S0261-5177(98)00073-9
Richards, G., 1999, 'Vacations and the quality of life: Patterns and structures', Journal of Business Research 44, 189-198. http://dx.doi.org/10.1016/S0148-2963(97)00200-2

Saayman, M., 2006, Travel motivations. Marketing tourism: Products and destinations, Leisure C Publications, Potchefstroom.

Saayman, M., Kruger, M. \& Fouché, M., 2010, 'Travel motives to Kruger and Tsitsikamma National Parks: A comprehensive study', South African Journal of Wildlife Research 40(1), 93-102. http://dx.doi.org/10.3957/056.040.0106

Saayman, M. \& Saayman, A., 2009, 'Creating a framework to determine the socioeconomic impact of national parks in South Africa: Case study of the Addo Elephant National Park', Koedoe 51(1), 49-57.

Seattle Times, 2010, 'Travel updates: National park visits surged in 2009', viewed 09 February 2010, from http://seattletimes.nwsource.com/html/travel/2011177054 trbriefs28.html

Song, H. \& Lin, S., 2010, 'Impacts of the financial and economic crisis on tourism in Asia', Journal of Travel Research 49(1), 16-30. http://dx.doi.org/10.1177/ 0047287509353190

South African National Parks (SANParks), 2009, 'National Parks report', viewed 15 February 2010, from http://www.sanparks.org/about/annual/2009.pdf

South African Tourism (SAT), 2009, South African Tourism Index July to September 2009, viewed 16 March 2010, from http://www2.southafrica.net/satourism/ research/viewResearchDetail.cfm?Action=Download\&FileID=30087\&ReportType CategoryID $=74$

Swanson, K.K. \& Horridge, P.E., 2005, 'Travel motivations as souvenir purchase indicators', Tourism Management 27(4), 671-683. http://dx.doi.org/10.1016/j. tourman.2005.03.001

Tao, C.H., Eagles, P.F.J. \& Smith, S.L.J., 2004, 'Implications of alternative definitions of ecotourism', Tourism Analysis 9(1-2), 1-13. http://dx.doi.org/10.3727/ of ecotourism', Touris

TheSafariCo, 2013, 'Kruger National Park map', viewed 26 January 2013, from http:// www.thesafaricompany.co.za/Map_Kruger.htm

Tourism Review, 2009, 'NWTO reports global decline in tourism arrivals', viewed 14 February 2010, from http://www.tourism-review.com/article/1713-global-tourismdeclined-by-8

Ulrich, R.S., 1983, 'Aesthetic and affective response to natural environment', Human Behaviour \& Environment: Advances in Theory \& Research 6, 85-125.

Uysal, M. \& Jurowski, C., 1994, 'Testing the push and pull factors', Annals of Tourism Research 21(4), 844-846. http://dx.doi.org/10.1016/0160-7383(94)90091-4

Uysal, M., McDondald, C.D. \& Martin, B.S., 1994, 'Australian visitors to US national parks and natural areas', International Journal of Contemporary Hospitality Management 6(3), 18-24. http://dx.doi.org/10.1108/09596119410059209

Van der Merwe, P \& Saayman, M., 2008, 'Travel motivations of tourists visiting Kruger National Park', Koedoe 50(1), 154-159. http://dx.doi.org/10.4102/koedoe. v50i1.140

Wilkerson, C., 2003, 'Travel and tourism: an overlooked industry in the U.S. and tenth district', viewed 10 March 2010, from http://www.kansascityfed.org/publicat/ econrev/PDF/3q03wilk.pdf

World Trade and Tourism Council (WTTC), 2009, 'Travel and tourism economic impact. World travel and tourism council', viewed 20 February 2010, from http://www. wttc.org/bin/pdf/original_pdf_file/middleeast.pdf 